\title{
Impact of Climate Change on Insects, Pest, Diseases and Animal Biodiversity
}

\author{
Nwaerema Peace* \\ University of Port Harcourt, Nigeria \\ Submission: January 09, 2020; Published: March 11, 2020 \\ *Corresponding author: Nwaerema Peace, University of Port Harcourt, Nigeria
}

Keywords: Climate change; Earth biodiversity; Environment; Arthropod insects; Temperature change; Bluetongue disease

\section{Introduction}

Climate change is the significant variation that has occurred in the global temperature, precipitation, wind patterns, humidity and other parameters of the earth's atmosphere over several decades. Human activities have contributed to a severe change in the global climate, resulting to decline in the earth biodiversity. Thus, climate change has directly or indirectly affected diverse life on the earth surface. Greatly, climate change affects man, vegetation and crops, fishes, pests and diseases, insects, animals, soil and the general ecosystems of the human environment. It is evident that some species are dying while others are adapting, the foods we eat are threatened and ecosystem in some regions is undergoing serious extinction [1]. However, giving solutions to the menace of climate change calls for multidisciplinary actions by predicting and sounding early warnings to global climate change impacts in order to gain support from the general public.

\section{Effects of Climate Change on Insects, Pests and Diseases}

Climate change has varied ways it can affect pests and diseases. Thus, $\mathrm{CO}_{2}$ as a contributor to climate change can raise the simple sugar level in the leaves and reduce the nitrogen substance. When this happens, sugar loving insects are attracted to damage the leaves [2]. It is expected that increased temperature will favor insects and pests to survive better during wet season and introduce extremely harsh weather to them during the dry season. For example, warm loving fungi (thermophilic fungi) will thrive well in warm temperature [2,3]. As the globe gets warmer, microbes, pathogens and pests will have the tendency to move poleward while leaving the equatorial region denied of their presence. Some microbes are beneficial to soil, crop and plants; therefore, their scarcity will impact negatively on soil, crop and plant species. With climate change in the polar region and favorable weather there will be serious attacks of pests, insects and diseases on plant and crop species. Also, increased temperature and $\mathrm{CO}_{2}$ have the tendency to cause interactions and create enmity between the pests and their natural hosts such as the effects seen among arthropod insects, like mosquitoes, midges, ticks, fleas and sandflies and their viruses [3].

Climate change can cause the expansion of diseases. In the process of unfavorable temperature conditions, disease carrying pathogens will migrate from its main origin to other parts as a form of adaptation and survival. For example, the epizootic ulcerative syndrome caused by fungi disease infected fish in the southern part of South Africa due to severe variation in temperature, rainfall and other related climatic conditions. Due to climate change, the Bluetongue disease which was formerly found in southern Europe since 1998 along the Mediterranean has migrated to the northern Europe which has affected cattle farmers [3]. The Coffee Borrow Beetle $\mathrm{CBB}$ ) increase in density due to increased temperature. The CBB can thrive extreme temperatures of $15-32^{\circ} \mathrm{C}$ and develop faster in temperature range of $27-30^{\circ} \mathrm{C}[4,5]$. Wet, rainy, windy but cold conditions favor the spread of bacterial blight fungus disease (Pseudomonas syringae pv garcae) and Coffee Berry Disease (Colletotrichum kahawae) easily spreads from the spores of trees after a wash to the bottom [6].

Temperature change affects insects directly since they are exothermic, therefore are more active under increased warmness. Thus, when temperature of the environment where an insect lives is increased, it will raise energy consumption rate and reduce pupation time as well as expose them to natural predators (Vikaspedia). For example, increased temperature will raise the activity of gypsy moth by reducing its time to grow and level of survival. Also, $2^{\circ} \mathrm{C}$ temperature variation can conditionally increase life cycle of insects up to 1 to 5 times in addition under normal conditions (Williams et al. 2003). Insects that borrow in the soil can survive better than those living on the surface 
because the soil provides insulation to soil temperature than air temperature which the surface insects suffer [7]. Insect species tend to reduce with higher latitude and altitude indicating that increased temperature will produce more insects attacking more crops in the temperate region and low-lying places will encourage more insects' attacks [7-9].

Rainfall variations can influence insect productivity. Rainfall change and delay can affect some insect pest predators, diseases and parasites of a particular food chain process as well as entire biodiversity setting of an area. For example, fungal pathogens of some insects prefer high humidity caused by abundant rainfall thereby increase their level of attacks on insects. Also, heavy rainfall can easily wash insects attacking crops since some are sensitive to rainfall resulting to increased yield of crops as in the case of onion thrips using precipitation as a good management priority [10].

\section{Effects of Climate Change on Animal Productivity}

It is obvious that climate change such as temperature, rainfall, humidity, wind, sunshine will directly or indirectly continue to alter the state of diseases and pests in any geographical location thereby affecting animal productivity [11]. Animals are hosts or prey to some insects, pests and microbes which their behavioral changes can attack or benefit the animals. Studies have shown that temperature rise can improve or decline the health conditions of animals especially in humid and wet areas [12-14]. Climate change can directly impact on animal through illnesses that result from temperature changes and the direct impacts are those carried by disease vectors, food, water and air [15]. For example, heat waves can cause serious psychological and metabolic disorder in animals thereby causing hyperthermia capable of reducing their productivity [16]. This condition could cause respiratory problems that may result to sweating and reduce food consumption as well as death. In cattle, increased temperature can cause lameness and respiratory alkalosis [17], clinical ketosis (Lacetera et al. 1996) and liver lipidosis [18].

Due to climate change, many studies have been conducted on stress caused by animal oxidation process $[19,20]$. The body metabolic temperature level of poultry birds is usually $30^{\circ} \mathrm{C}$, which in excess will result to energy loss and poor feeding. In heifer's serum, antioxidants level was found to lower in the dry season than in wet season [21]. In the middle of a lactating cow, the metabolic substances were raised during the dry (summer) season due to increased temperature. The immune system of animals can be impaired by increased temperature resulting from heat stress. For instance, the immune system of avian species and dairy cows were impaired due to heat stress [11,22].

High temperature can impair the neutrophils of the cow mammary gland and mastitis disease can occur due to bacteria destruction of the animal teat canal which occurs more during the summer $[23,24]$. Epidemiologically, increased heat could cause the survival and spread of more pathogens and vectors in different regions of the world. Many researches have established more deaths of animals due to heat stress in extreme weather conditions such as death of more Mecheri sheep during summer (Purusothaman et al. 2008; Hahn et al. 2002; Vitali et al. 2015) $[25,26]$.

Indirectly, climate change can influence biological distribution of vector borne diseases. In the globe, temperature, rainfall, humidity and wind vary from place to place. Therefore, the activities, population, reproduction and consequences of vectors will be felt differently among regions of the world. For example, an increased temperature of $2^{\circ} \mathrm{C}$ can result to rapid spread of Culicoides imicola as key vector of the bluetongue virus [27]. As climate change takes place, diseases caused by parasite will rise. In some region of the world, there will be increased disease outbreak and some part may witness reduced outbreak of diseases too based on the type of disease parasite or vector available at a given time and space.

\section{Conclusion}

Climate change impacts have been linked to global ecosystem of fishery, pests and diseases, insect and animals. Man is the center and controller of the global biodiversity. Therefore, effort is needed to understand, prevent and management as well as mitigate the impacts of climate change on biological resources. These involve reducing emissions of greenhouse gases and pollution of air, land, water as well as prevent deforestation; also undertaking activities such as afforestation, conservation and the sustainable management of forests, vegetation and crops as well as animals. Both public and private sectors should be engaged to cushion the effect of climate change on biological resources.

\section{References}

1. European Environment Agency [EEA]. Greenland and Antarctic ice sheets.

2. Venkataraman S (2016) Down To Earth. How is climate change affecting crop pests and diseases?

3. Danielle G (2018) The Effects of Climate Change on the Pests and Diseases of Coffee Crops in Mesoamerica. Climatol Weather Forecasting 6: 239.

4. Laderach P, Haggar J, Lau C, Eitzinger A, Ovalle O, et al. (2010). Mesoamerican Coffee: Building a Climate Change Adaptation Strategy. CIAT Policy Brief 2: 1-4.

5. Living with Environmental Change Network (LECN). Biodiversity Climate Change Impacts. Report Card 2015.

6. Kimani M, Little T, Vos JGM (2002) Introduction to coffee management through discovery learning. Farmer Participatory Training and Research Program. CABI Bioscience Kenya, p. 35.

7. Bale JS, Masters GJ, Hodkinson ID, Awmack C, Bezemer TM, et al. (2002). Herbivory in global climate change research: direct effects of rising temperature on insect herbivores. Global Change Biology 8(1): $1-16$. 
8. Harrington R, Fleming RA, Woiwod IP (2001) Climate change impacts on insect management and conservation in temperate regions: can they be predicted? Agricultural and Forest Entomology 3(4): 233-240.

9. Andrew NR, Hughes L (2005) Diversity and assemblage structure of phytophagous Hemiptera along a latitudinal gradient: predicting the potential impacts of climate change. Global Ecology and Biogeography 14(3): 249-262.

10. Reiners S, Petzoldt C (2005) Integrated Crop and Pest Management Guidelines for Commercial Vegetable Production. Cornell Cooperative Extension Publication \#124VG.

11. Nicola L (2019) Impact of climate change on animal health and welfare. Animal Frontiers 9(1): 26-31.

12. Ballester J, Robine JM, Herrmann FR, Rodo X (2011) Long-term projections and acclimatization scenarios of temperature-related mortality in Europe. Nat Commun 2: 358.

13. Rose H, Wang T, van Dijk J, Morgan ER (2015) A simulation model of the effects of climate and climate change on the free-living stages of gastro-intestinal nematode parasites of ruminants. Ecol Mod 297: 232245

14. Rabinowitz P, Conti L (2013) Links among human health, animal health, and ecosystem health. Annu Rev Public Health 34: 189-204.

15. Lacetera N (2012) Effect of environment on immune functions. In: Collier RJ, Collier JL (Eds.), Environmental physiology of livestock. Chichester (England), Wiley-Blackwell, pp. 165-179.

16. Gaughan JB., Lacetera N, Valtorta SE, Khalifa HH, Hahn GL, et al. (2009) Response of domestic animals to climate challenges In: Ebi KL, Burton I, McGregor GR (Eds.), Biometeorology for adaptation to climate variability and change. Heidelberg (Germany) Springer-Verlag, pp. 131-170.

17. Shearer JK (1999) Foot health from a veterinarian's perspective. Proc Feed Nutr Manag Cow Coll Virg Tech, pp. 33- 43.

18. Basirico L, Bernabucci U, Morera P, Lacetera N, Nardone A (2009) Gene expression and protein secretion of apolipoprotein B100 (ApoB100) in transition dairy cows under hot or thermoneutral environments. Proc XVIII Congr Naz Ass Sci Prod Anim 8: 592- 594.
19. Bernabucci, U. Ronchi, B. Lacetera N, Nardone A (2002) Markers of oxidative status in plasma and erythrocytes of transition dairy cows during hot season. J Dairy Sci 85(9): 2173-2179.

20. Akbarian A, Michiels J, Degroote J, Majdeddin M, Golian A, et al. (2016) Association between heat stress and oxidative stress in poultry; mitochondrial dysfunction and dietary interventions with phytochemicals. J Anim Sci Biotechnol 7: 37.

21. Mirzad AN, Tada T, Ano H, Kobayashi I, Yamauchi T, et al. (2018) Seasonal changes in serum oxidative stress biomarkers in dairy and beef cows in a daytime grazing system. J Vet Med Sci 80(1): 20-27.

22. Lacetera N, Segnalini M, Bernabucci U, Ronchi B, Vitali A, et al. (2013) Climate induced effects on livestock population and productivity in the Mediterranean area. In: Navarra A, Tubiana L (Eds.), Regional assessment of climate change in the Mediterranean. Advances in global change research 51. Dordrecht (The Netherlands): Springer Science + Business Media, pp. 135-156.

23. Lecchi C, Rota N, Vitali A, Ceciliani F, Lacetera N (2016). In vitro assessment of the effects of temperature on phagocytosis, reactive oxygen species production and apoptosis in bovine polymorphonuclear cells. Vet Immunol Immunopathol 182: 89-94.

24. Vitali A, Bernabucci U, Nardone A, Lacetera N (2016) Effect of season, month and temperature humidity index on the occurrence of clinical mastitis in dairy heifers. Adv Anim Biosci 7(3): 250-252.

25. Dechow CD, Goodling RC (2008) Mortality, culling by sixty days in milk, and production profiles in high- and low-survival Pennsylvania herds J. Dairy Sci 91(12): 4630-4639.

26. Vitali A, Segnalini M, Bertocchi L, Bernabucci U, Nardone A, et al. (2009). Seasonal pattern of mortality and relationships between mortality and temperature-humidity index in dairy cows. J Dairy Sci 92(8): 3781-3790.

27. Wittmann EJ, Mellor PS, Baylis M (2001) Using climate data to map the potential distribution of Culicoides imicola (Diptera: Ceratopogonidae) in Europe. Rev Sci Tech 20: 731-740.

\section{Your next submission with Juniper Publishers} will reach you the below assets

- Quality Editorial service

- Swift Peer Review

- Reprints availability

- E-prints Service

- Manuscript Podcast for convenient understanding

- Global attainment for your research

- Manuscript accessibility in different formats

( Pdf, E-pub, Full Text, Audio)

- Unceasing customer service

Track the below URL for one-step submission https://juniperpublishers.com/online-submission.php 